\title{
АДМІНІСТРАТИВНО-ПРАВОВЕ РЕГУЛЮВАННЯ МИТНИХ РЕЖИМІВ В ЯПОНСЬКІЙ ДЕРЖАВІ ТА КИТАЙСЬКІЙ НАРОДНІЙ РЕСПУБЛІЦІ
}

Вступ. Сучасний стан митних відносин в Україні є задовільним та потребує удосконалення з урахуванням позитивного досвіду зарубіжних країн у сфері правового регулювання митних режимів, якими безпосередньо визначаються митні процедури щодо товарів, які переміщуються через митний кордон України, їх правовий статус, умови оподаткування та використання після митного оформлення. Так, за результатами соціологічного дослідження Європейської Бізнес-Асоціації, проведеного у 2018 році, 36,2\% опитаних представників бізнесу не задоволені якістю митних послуг та професіоналізмом осіб, з якими вони взаємодіють на митниці, 58,6\% вважають, що корупція в митних органах залишається на тому ж рівні [1]. У першому півріччі 2020 року результати опитування демонструють, що оцінка роботи митниці експертами Асоціації залишається концептуально незмінною протягом останнього року. Так, 56\% вважають, що корупція в митних органах залишається на тому ж рівні [2].

Враховуючи вищевикладене, актуальним вважаємо дослідження досвіду адміністративно-правового регулювання митних режимів у країнах, які вже сформували стабільні та перевірені часом системи митного оформлення й контролю. На увагу заслуговує позивний досвід адміністративно-правого регулювання митних режимів в Японській Державі та Китайській Народній Республіці, які демонструють високі показники розвитку економіки та $€$ активними учасниками міжнародного ринку.

Питання адміністративно-правового регулювання митних відносин в Україні досліджуються в роботах фахівців у сфері адміністративного права, серед яких слід назвати роботи О. Бандурки, В. Бевзенка, Н. Білак, М. Віхляєва, Н. Губерської, С. Гусарова, Р. Калюжного, Т. Коломоєць, В. Колпакова, А. Комзюка, О. Кузьменко, В. Курила, Д. Лук'янця, Д. Лученка, П. Лютікова, М. Мельника, Р. Мельника, О. Миколенка, Я. Назарової, Н. Нижник, Д. Приймаченка, С. Стеценко, М. Тищенка, О. Чуприни, А. Школика та інших учених-адміністративістів. Серед останніх досліджень слід відзначити дисертаційну роботу $M$. Мельника «Інститут митних режимів в митному праві України» [3], публікаціï I. Міщенко «Новели інституту митного режиму в контексті реформування митного законодавства» [4], В. Хоми «Сучасний стан національного правового забезпечення митного режиму безмитної торгівлі та напрями його вдосконалення» [5], О. Чуприни «Класифікація митних режимів у юридичній науці та законодавстві» [6] та А. Мостового «Функціі митних режимів: порівняльна характеристика 3 митним правом Європейського Союзу» [7]. Проте правове 
регулювання митних режимів в Японській Державі та Китайській Народній Республіці досліджено в доктрині адміністративного права недостатньо повно, чим обгрунтовується актуальність підготовки публікації.

Методологія дослідження грунтується на комплексному поєднанні філософських (законів діалектики та метафізики), загальнонаукових (прийомів логічного методу, системного та структурно-функціонального методів) та спеціально-юридичних методів дослідження (методологіі порівняльного правознавства, методів юридичної догматики та юридичного моделювання тощо), принципів об'єктивності та історизму.

Постановка завдання. Метою наукової публікації $€$ дослідження досвіду правового регулювання митних режимів в Японській Державі та Китайській Народній Республіці, а також визначення можливості його впровадження в національне законодавство та юридичну практику з урахуванням національних традицій, рівня правосвідомості та правової культури громадян України.

Результати дослідження. Позитивнийдосвідадміністративно-правового регулювання митних режимів в Японській Державі формувався протягом тривалого часу під впливом багатьох факторів, серед яких ключову роль відіграли технологічна революція та розумна зовнішньоекономічна політика японського уряду, спрямована на підтримку та захист національного виробника. Нині Японія є одним зі світових лідерів у сфері міжнародної торгівлі та здійснює активну інвестиційну діяльність.

В адміністративно-правовому регулюванні митних відносин Японії привертає увагу Генералізована система преференцій, яка призначена для сприяння економічному зростанню в країнах, що розвиваються та покликана збільшити доходи цих країн від експорту. Генералізована система преференцій Японіі передбачає, що імпорт понад 3500 видів товарів з України та інших країн, що розвиваються, здійснюється без сплати ввізного мита або зі сплатою мита нижче загального рівня. Ця система заснована 1 серпня 1971 року та діє до 31 березня 2021 року. Бенефіціарами Генералізованої системи преференцій Японії є 135 країн і 5 територій, в тому числі Україна. До продукції, що підпадає під преференційний режим імпорту, а саме за ставками ввізного мита нижче загального рівня та нульовими, належить таке:

- сільськогосподарські товари (408 кодів на 9 знаках Митного тарифу Японіi), зокрема м'ясо та їстівні субпродукти індиків, качок, гусей; сало, цикорій, артишок, картопля, малина, ожина, журавлина, житнє борошно, вівсяна крупа, готова або консервована риба, огірки, корнішони, томати, води мінеральні та газовані, пиво із солоду;

- промислова продукція (3 151 код на 9 знаках Митного тарифу Японіi), зокрема цемент, аміак, гідрооксид натрію, оксид титану, різні види хімічних речовин та мінералів, папір та картон, пряжа лляна, нитки швейні із синтетичних або штучних волокон, головні убори, парасольки, посуд та прибори столові або кухонні; гвинти, болти, гайки та аналогічні вироби, з чорних металів; ножі, ножиці, електроди, вудки, гачки, котушки риболовні; термоси [8].

Загальний обсяг імпорту товарів в рамках програми Генералізованої системи преференцій Японії складає понад 38 млрд. дол. США. Протягом 2011-2016 років Україна експортувала до Японії товари, що підпадали під дію Генералізованої системи преференцій на суму від 8,5 до 36 млн. дол. США, зокрема титан необроблений; порошки, пігменти та препарати, виготовлені на основі діоксиду титану; оксид титану; ємності для стиснених або скраплених газів, з чорних металів; іграшки; аміак; аксесуари до одягу з пластику.

Товари повинні транспортуватися безпосередньо до Японії без проход- 
ження через будь-які інші території. Водночас товари, що транспортуються в Японію через території інших країн, мають право на отримання пільгового режиму, якщо вони не піддавалися будь-якій обробці в країнах транзиту, крім перевантаження або тимчасового зберігання виключно внаслідок транспортних вимог; перевантаження або тимчасове зберігання було здійснено на митних складах або будь-якому іншому подібному місці під контролем митних органів країн транзиту [8].

Як правило, товар має бути повністю вироблений в Україні. Водночас якщо товар вироблений повністю або частково 3 матеріалів або деталей, які імпортуються 3 інших країн чи $€$ невідомого походження, то такий товар вважатиметься таким, що походить з України, якщо ці матеріали або деталі зазнали достатнього оброблення. Роботи або операції з оброблення вважаються достатніми, коли вироблений товар класифікується відповідно до товарної позиції Гармонізованої системи на рівні 4 цифр. Водночас деякі роботи або операції з оброблення не будуть вважатися достатніми, якщо такі роботи або операції з оброблення є занадто простими, навіть якщо є зміни в товарній позиції Гармонізованої системи.

Для того щоби товари отримали преференційний митний режим під час ввезенні їх до Японії, японським митним органам слід надати сертифікат походження товару за формою «A» (об’єднана декларація і сертифікат). Сертифікат видається митними органами (або іншими компетентними державними органами країни-експортера, яка отримала преференційний режим, або іншими органами цієї краіни, такими, як торгові палати, які зареєстровані як емітенти японських митних органів) на підставі заяви від експортера, коли він експортує відповідні товари. Водночас для партій товарів, митна вартість яких не перевищує 200000 ієн (орієнтовно
$\$ 1$ 800), або товарів, походження яких $€$ очевидним, такий сертифікат не вимагається [8].

Таким чином, Японія як розвинута держава зі стабільною ринковою економікою та високим показником валового внутрішнього продукту може собі дозволити застосовувати вищезазначену Генералізовану систему преференцій, створену для сприяння економічному зростанню в країнах, що розвиваються. Для України такий досвід $є$ позитивним для застосування у перспективі. Для розвитку національної митної справи більш корисним $є$ досвід правового регулювання митних режимів в Китайській Народній Республіці.

Митна служба Китайської Народної Республіки - це державний орган контролю за пропуском через кордон у прикордонних пунктах. Китайська економіка демонструє надзвичайно високі темпи зростання протягом останніх років. Це пояснюється багатьма економічними чинниками, серед яких важливе місце належить виваженій митно-тарифній політиці. Однією з головних рушійних сил зростання китайської економіки $€$ експорт, і в країні було зроблено все на законодавчому та виконавчому рівнях для його підтримки, а також для захисту стратегічних галузей. Головна митна адміністрація - це державний орган виконавчої влади, безпосередньо підпорядкований Державній раді КНР, що здійснює єдине управління митницями по всій країні, входить до структури організацій, що діють безпосередньо при Державній раді КHР. Державна рада засновує Головне митне управління, здійснює єдине управління митницею по всій країні. Держава засновує митниці в портах, відкритих для зовнішніх зв'язків, і в місцях проведення операцій митного контролю. На митні операції не поширюються обмеження, пов'язані 3 адміністративним поділом. Митниці, відповідно до закону, незалежні у виконанні своїх функцій, підпорядковуються Головному митному управлінню [9; 10, с. 82]. Діяльність 
митної служби КНР характеризується активністю проведення семінарів для митних служб різних держав, забезпеченням підготовки 3 митних питань служб інших держав, активною участю в різних міждержавних програмах. Значна увага приділяється досягненню мети «добросусідства, дружнього партнерства та майбутніх перспектив» у процесі співпраці 3 іншими країнами; підтриманню та збагаченню національної економіки, розробленню програм удосконалення зовнішньоекономічної діяльності, боротьбі з контрабандою та спрощенню процедур справляння податків і зборів [9, с. 111-112].

Митна служба Китаю, маючи штат співробітників понад 48000 осіб, забезпечує ефективний митний контроль у 247 портах. Митниця Китаю має міжнародні офіси в Брюсселі, Москві, Вашингтоні. Головна митна адміністрація складається 3 таких відділів: Головне управління; відділ із правових питань та політики; відділ нагляду у сфері торгівлі та оброблення податкової зони; відділ статистики; відділ боротьби з контрабандою; бюро кримінальних розслідувань; відділ технологій та розвитку; відділ міжнародного співробітництва; відділ фінансів; відділ персоналу та освіти.

Основними функціями та завданнями Митної служби КНР є такі:

- фіскальна (оцінювання, стягнення й повернення мита, митних зборів і платежів; митний контроль та митне оформлення товарів і транспортних засобів);

- правоохоронна (захисна) (боротьба 3 контрабандою; огляд транспортних засобів і контейнерів; пасажирський контроль, захист прав інтелектуальної власності);

- інформаційна (ведення митної статистики).

Щодо повноважень митної служби КНР, то вони закріплені Митним кодексом КНР від 1987 року. До них, зокрема, належать такі:

- митний контроль (відповідно до стандартизованої процедури, під час оформлення митниця перевіряє всю документацію і контролює потоки вантажу);

- адміністрування митних платежів (митниця справляє мито, внутрішні податки та відповідні збори, стягуючи їх від імені інших органів 3 імпорту та експорту);

- боротьба з контрабандою, ії виявлення та припинення, націлені на ліквідацію контрабандної діяльності загалом;

- ведення митної статистики (митниця збирає, обробляє інформацію за документами декларацій для складання та аналізу статистичних даних щодо цін (митної вартості товарів та транспортних засобів), способів торгівлі товарами; держава створила впорядкований механізм управління, що добре функціонує, застосовуючи для оптимізації своєї роботи автоматизовані системи з прийняття рішень, організації та координації, нагляду, оцінювання, моніторингу й аналізу).

На відміну від більшості країн світу, де митне оформлення переважно відбувається за місцем призначення товару, в Китаї майже весь імпорт оформляється в кількох основних митницях, які працюють у найбільших портах. Для оформлення експорту створено 15 бондових зон, які характеризуються найвищим ступенем відкритості й наданням зареєстрованим у них підприємствам пільг і сприяння під час експортних операцій.

Тарифна політика Китаю надзвичайно послідовна та виважена. На початку 2000-х років середньоарифметична ставка мита в Китаї дорівнювала понад $43 \%$ і була однією 3 найвищих у світі, що забезпечило комфортні умови для розвитку потужних промислових галузей. У 2001 році відбулося перше значне зниження митних тарифів, середньоарифметична ставка мита становила $23 \%$. Вступ країни до Світової організації торгівлі у 2002 році спричинив ще кілька вже вимушених знижень ставок мита, 2006 року 
середньоарифметична ставка становила лише 10,4\%. У 2012 році митниця Китаю доклала зусиль, щоб закріпити успіх, якого вона досягла у сфері справляння митних платежів. Це були такі заходи: повна реалізація податку на додану вартість; посилення контролю за логістикою; застосування аналізу управління ризиками та забезпечення незалежної оцінки митної вартості товарів для захисту від можливої втрати доходів у ключових галузях промисловості; перевірки за важливими й чутливими секторами щодо товарів. Спираючись на передовий досвід і методи, прийняті міжнародними митними спільнотами, Китайська митниця стала більш адаптованою до міжнародної митної практики [9, с. 113].

Вищезазначений досвід стимулювання експорту та гнучкої тарифної політики Китаю заслуговує на увагу і впровадження в національне законодавство та юридичну практику. Ключовою в цьому досвіді є політика захисту національного виробника та стимулювання національної промисловості завдяки системі заходів тарифного й нетарифного регулювання в процесі функціонування митних режимів. Зокрема, митний режим експорту має бути максимально спрощеним у поєднанні з ефективним контролем з боку публічної адміністрації задля недопущення фіктивного відшкодування податку на додану вартість та інших зловживань. Водночас митний режим імпорту має передбачати виконання суворих митних формальностей задля ефективного контролю дотримання податкового, митного, екологічного законодавства, а також законодавства у сфері захисту прав споживачів. Особливу увагу необхідно приділяти контролю якості промислових та продовольчих товарів, перевірці сертифікатів відповідності задля недопущення переміщення через митний кордон України небезпечної або неякісної продукції. Крім того, в рамках митного режиму імпорту необхідно застосовувати гнучку систему захо- дів тарифного та нетарифного регулювання задля стимулювання імпорту товарів, які не виробляються в Украіні, а також обмеження імпорту товарів, які достатньою мірою випускаються національними підприємствами. Розвитку потребує митний режим переробки на митній території України (який активно використовується в КНР) завдяки достатньо невисокій вартості праці та потенціалу розвитку національної економіки.

Висновки. Проведене дослідження дало змогу сформулювати висновок про те, що Японія як розвинута держава зі стабільною ринковою економікою та високим показником валового внутрішнього продукту може собі дозволити застосовувати систему преференцій, створену для сприяння економічному зростанню в країнах, що розвиваються. Для України такий досвід $є$ позитивним щодо застосування у перспективі. Для розвитку національної митної справи більш корисним $є$ досвід правового регулювання митних режимів у Китайській Народній Республіці. Зокрема, позитивним є досвід стимулювання експорту та гнучкої тарифної політики в Китайській Народній Республіці. Ключовою в цьому досвіді $€$ політика захисту національного виробника та стимулювання національної промисловості завдяки системі заходів тарифного й нетарифного регулювання в процесі функціонування митних режимів. Для національної економіки задля вирівнювання торгового балансу важливим $є$ збільшення експортних операціі, тому адміністративно-правове регулювання митного режиму експорту має бути максимально спрощеним та привабливим для суб'єктів зовнішньоекономічної діяльності. Не менш важливим $є$ якісне адміністративно-правове забезпечення функціонування митного режиму переробки на митній території України, що гарантуватиме створення нових робочих місць та збільшення надходжень до Державного бюджету України. 
Підсумовуючи, зазначаємо, що сліпе запозичення зарубіжного досвіду адміністративно-правового регулювання митних відносин $є$ неприпустимим, адже ключову роль у забезпеченні ефективності правового регулювання відіграє рівень правосвідомості та правової культури громадян, а також національні правові традиції та звичаї. На правові традиції Японії та Китаю значний вПлив здійснює філософія конфуціанства, яка грунтується на моральних догмах та ритуалах. Як у Японській Державі, так і в KНP виховання морально-правових цінностей здійснюється із самого дитинства, саме цей досвід заслуговує на увагу, запозичення та впровадження в національну практику правового виховання. Навіть ідеальні з точки зору юридичної техніки митні норми суб'єкт зовнішньоекономічної діяльності намагатиметься обійти, якщо він із самого початку має установку на порушення митних правил та ухилення від належного митного оформлення й контролю. Це ж стосується представників публічної адміністрації в особі посадових осіб Державної митної служби України, рівень професійної правової свідомості та правової культури яких більшою мірою, ніж інші фактори, визначає готовність дотримуватися норм митного права та не допускати проявів корупції в процесі функціонування митних режимів.

Перспективність подальшого наукового дослідження 3 цієї тематики обумовлена необхідністю подальшого удосконалення теоретико-методологічних та правових засад митних режимів в Україні, приведення їх у відповідність до міжнародних стандартів 3 урахуванням актуального та найкращого позитивного досвіду зарубіжних країн.

У науковій публікації досліджується адміністративно-правове регулювання митних режимів в Японській Державі та Китайській Народній Республіиі задля запозичення найкращого позитивного досвіду організаиіі митної справи та визначення можливості його впровадження в національне законодавство та юридичну практику.

Актуальність статті обтрунтовується тим, що, як показують дослідження, значна кількість суб'єктів зовнішньоекономічної діяльності в Україні не задоволена якістю митних послуг та професіоналізмом осіб, з якими вони взаємодіють на митниці (представники компаній вказують на нестачу злагодженої взаємодії між контролюючими органами та низьку активність митниці щзодо координациї такої взаємодії).

Методологія публікациї грунтується на комплексному поєднанні філософських (законів діалектики та метафізики), загальнонаукових (прийомів логічного методу, системного та структурно-функціонального методів) та спеціально-юридичних методів дослідження (методології порівняльного правознавства, методу юридичного моделювання тощо), принцииів об’єктивності та історизму.

Формується висновок про те, що Японія як розвинута держава зі стабільною ринковою економікою та високим показником валового внутрішнього продукту застосовує систему преференцій, створену для сприяння економічному зростанню в країнах, що розвиваються. Для України такий досвід є позитивним для застосування у перспективі. Для розвитку національної митної справи більш корисним є досвід правового регулювання митних режимів y Китайській Народній Республіці. Зокрема, позитивним є досвіо стимулювання експорту та гнучкої тарифної політики в Китайській Народній Республіці. Ключовою в изьому досвіді є політика захисту національного виробника та стимулювання національної промисловості завдяки системі заходів тарифного та нетарифного регулювання 
в процесі функціонування митних режимів. Зокрема, митний режим експорту має бути максимально спрощеним у поєднанні з ефективним контролем з боку публічної адміністращії задля недопущення фактів фіктивного відшкодування податку на додану вартість та інших зловживань. В рамках митного режиму iмnорту необхідно застосовувати гнучку систему заходів тарифного та нетарифного регулювання задля стимулювання імпорту товарів, які не виробляються в Україні, та обмеження імпорту товарів, які достатньою мірою випускаються національними підприємствами. Розвитку потребує митний режим переробки на митній території (який активно використовується в КНР) завдяки достатньо невисокій вартості праці в Україні та потенціалу розвитку національної економіки.

Перспективність подальшого дослідження з ијеї тематики обтрунтовується необхідністю удосконалення теоретико-методологічних та правових засад митних режимів в Україні, приведення їх у відповідність до міжнародних стандартів з урахуванням актуального та найкращого позитивного досвіду зарубіжних країн.

Ключові слова: митні режими, зарубіжний досвід, митна справа, митні процедури, митні відносини, митне оформлення, митний контроль, адміністративне право, публічна адміністрація, удосконалення.

Lemekha R. Administrative and legal regulation of customs regimes in the state of Japan and the People's Republic of China The scientific publication is devoted to the administrative and legal regulation of customs regimes in the State of Japan and the People's Republic of China in order to learn the best positive experience in organizing customs and determine the possibility of its implementation in national legislation and legal practice.
The relevance of this study is justified by the fact that, as studies show, a significant number of foreign economic entities in Ukraine are not satisfied with the quality of customs services and professionalism of persons with whom they interact at customs (company representatives point to lack of coordinated cooperation between regulators customs to coordinate such interaction).

The methodology of this publication is based on a complex combination of philosophical (laws of dialectics and metaphysics), general scientific (methods of logical method, system and structural-functional methods) and special legal research methods (methodology of comparative law, method of legal modeling, etc.) and principles of objectivity historicism.

It is concluded that Japan, as a developed country with a stable market economy and high gross domestic product, can afford to apply a system of preferences designed to promote economic growth in developing countries. For Ukraine, such an experience is positive for future application. The experience of legal regulation of customs regimes in the People's Republic of China is more useful for the development of national customs. In particular, the experience of export promotion and flexible tariff policy in the People's Republic of China is positive. The key in this experience is the policy of protection of the national producer and stimulation of the national industry thanks to the system of measures of tariff and non-tariff regulation in the course of functioning of customs regimes. In particular, the customs regime of exports should be simplified as much as possible in combination with effective control by the public administration in order to prevent the facts of fictitious reimbursement of value added tax and other abuses. Within the framework of the customs import regime, it is necessary to apply 
a flexible system of tariff and nontariff regulation measures in order to stimulate the import of goods not produced in Ukraine and to restrict the import of goods sufficiently produced by national enterprises. The customs regime of processing in the customs territory (which is actively used in China) needs to be developed, given the rather low cost of labor in Ukraine and the potential for development of the national economy.

Prospects for further research on this topic is justified by the need to improve the theoretical and methodological and legal framework of customs regimes in Ukraine, bringing them into line with international standards, taking into account the current and best positive experience of foreign countries.

Key words: customs regimes, foreign experience, customs business, customs procedures, customs relations, customs clearance, customs control, administrative law, public administration, improvement.

\section{Література}

1. Європейська Бізнес-Асоціація оприлюднила результати Митного індексу / Європейська Бізнес-Асоціація. Дата оновлення: 28 серпня 2018 року. URL: https:// eba.com.ua/yeuropejskabiznes-asotsiatsiya-oprylyudnyla-rezultatymytnogo-indeksu.

2. Бізнес не бачить зрушень у реформуванні митниці / Європейська БізнесАсоціація. Дата оновлення: 2 липня 2020 рокy. URL: https:// eba.com.ua/ biznes-ne-bachyt-zrushen-u-reformuvannimytnytsi.

3. Мельник М. Iнститут митних режимів в митному праві України : дис. ... канд. юрид. наук : спеи. 12.00.07 «Адміністративне право і процес; фінансове право; інформаційне право» ; Міжрегіональна академія управління персоналом. Київ, 2016. 251 с.

4. Міщенко I. Новели інституту митного режиму в контексті реформування митного законодавства. Адміністративне право і процес. 2012. № 2. С. 73-77.

5. Хома В. Сучасний стан національного правового забезпечення митного режиму безмитної торгівлі та напрями його вдосконалення. Юридичний науковий електронний журнал. 2019. № 5. C. 104-108. URL:http: / / www.lsej.org.ua/ 5_2019/25.pdf.

6. Чуприна О. Класифікація митних режимів у юридичній науці та законодавстві. Право та інновації. 2015. № 2 (10). С. 133-139.

7. Мостовий А. Функиії митних режимів: порівняльна характеристика з митним правом Європейського Союзу. Вісник Львівського національного університету. Серія: Юридична. 2008. Bun. 47. С. 90-95.

8. Генералізована система преферениій Японії / Міністерство розвитку економіки, торгівлі та сільського господарства України. Міжнародна торгівля. URL: https: / / www.me.gov.ua / Documents / Detail? lang =uk-UA\&id=\{3e3391f-a19a4fdf-9e4d-9e24708b6446\&title $=$ Generalizov anaSistemaPreferentsiiYaponii\&isSpecial $=t$ rue.

9. Коляда С., Алмаз Л., Гребенок О. Митні служби Китаю та Японії в контексті зовнішньої економічної діяльності. Вісник Академії митної служби України. Серія: Економіка. 2013. № 1 (49). С. 110-117.

10. Eнамура Н., Цукамото X. Onьт послевоенной Японии в реформировании экономики. Вопросы экономики. 1992. № 11. C. 82-85. 